\title{
The Factors that are Dictating the Buyer Supplier Relationship
}

\section{in the Retail Market}

\author{
Saba Asghar ${ }^{1}$ \\ ${ }^{1}$ Bahria college karsaz Karachi, Pakistan \\ Correspondence: Saba Asghar, Bahria college karsaz Karachi, Pakistan
}

Received: November 13, 2017

Accepted: September 20, 2018

Online Published: September 27, 2018

doi:10.5430/bmr.v7n3p50

URL: https://doi.org/10.5430/bmr.v7n3p50

\begin{abstract}
Healthy relationship among the buyer and supplier is the only way to remain competitive in the incentive market. It is the only way to retain the business and the customers. If buyer and supplier are not having this partnership then they might not be enjoying the best outcomes.

The objective of this thesis is to examine the core factors that dictate buyer (Super Market) and Supplier (Distributor) relationship in retail industry. In this research, aspects has been studied that could have affected or affects the relationship of buyer \& supplier in positive or negative manner. The research has covered the retail market and will be dictating the key aspects of maintaining the healthy buyer and supplier relationships. This will be helping the retail owners and retail brands to gain the competitive edge from others and always remain ahead. This research will help both the stakeholders of this industry to maintain healthy relationships between them and indicates them that what the issues that create problems between them are.

The thesis employed an empirical approach designed in three stages; aggregate and firm level analysis using official data, firm level analysis using survey and finally case studies aimed at providing deeper insights into the underlying issues observed in the survey findings. Three literature strands were adopted: spillover, cluster and network dynamics.
\end{abstract}

Keywords: factors, dictate, buyer, supplier, retail market

\section{Introduction}

Intense competition and shortening of the product life cycles have forced the business giants to work more on business competencies and maintaining the mutual beneficial relationship with the suppliers. It will be providing competitive edge to the business (Kim, 2008). Broad business success depends over the appropriate linkage between the suppliers and the buyer. It is very important to select the right supplier for the business; it will dictate the development of infrastructure and reducing the competition's pressure. It is also necessary, nowadays, to create the value add chain by developing the healthy relationship with the suppliers (Kannan \& Tan, 2006). Fro dell (2011) has also admitted that the achievement of efficient contract supplier relations will give advantages over cutting costs, value creations, and involvement in the contracts and reducing the lead times. He also highlighted that it is very essential to have collaboration from both the ends.

The research will be covering the retail market and will be dictating the key aspects of maintaining the healthy buyer and supplier relationships. This will be helping the retail owners and retail brands to gain the competitive edge from others and always remain ahead.

\section{Review of Related Literature}

\subsection{Theoretical}

Healthy relationship among the buyer and supplier is the only way to remain competitive in the incentive market. It is the only way to retain the business and the customers. If buyer and supplier are not having this partnership then they might not be enjoying the best outcomes (Donald, 1996). Oh and Kim (2011) has also admitted that the buyer and supplier relationship is very important to affect the SCM. It also offers new business opportunities of the business. Donald (1996) has also admitted that the healthy relationship among buyer and supplier have many benefits. That includes, the demand forecasting from the supplier's side, sharing expertise, reducing cost and eliminating the conflicts through communication. 
Oh \& Kim (2011) have admitted the importance of information technology in developing the healthy relationship among the buyer and supplier. Humphreys et al. (2006) have also confessed the importance of introduction of B2B e-commerce. It has power to establish the buyer and supplier relationship and it has become the breakthrough in the traditional buyer and supplier relationship.

The complexity of the culture is very difficult for the suppliers to tackle, without having the healthy relationship with the buyers. That is the reason; buyer and supplier's healthy relationship is very important for dictating the need of the customers (Sternquist \& Chen, 2006).

\subsection{Empirical}

Fro"dell (2011) has studied the criteria for achieving efficient contractor supplier relations. The variables, which he has considered are: quality, sub optimization, cost reduction and efficient management of contractors and supplier relationship. He has used the qualitative paradigm of study. Observations, case study and interviews are the tools that are used for capturing the data. The result obtained from these tools have highlighted following things: The development and collaboration with the supplier must be the first priority, if any business want to achieve the efficiencies in core values and cost. Long term orientation is very necessary for making the high class relationship with the supplier.

Hald \& Ellegaard (2011) have investigated the supplier evaluation processes: the shaping and reshaping of supplier performance. They have included the variables like relationship, key account management, commitment, communication, project management, confidentiality, code of conduct, management, professionalism, inquiry reaction time, new ideas, IT set-up, economic development, proactive, technology, fast prototypes, master and prove new technologies, master simulations/virtual prototyping, responsibility/new components, delivery on time, order confirmation, spontaneous part deliveries, invoicing, quality, measurement capability, process control capability, inspection procedures, quality report and answers to CAR. They have used the mixed approached for analyzing the data. The case study analysis has been done for qualitative paradigm and factor analysis. They found that that defining, redefining and redirecting evaluation practices are depended on IT system, organization structure and available data source.

Lau (2011) has studied the implementation of social responsibility in purchasing in Hong Kong or the Pearl River Delta. He has chosen the variables including: environment, ethics, health and safety, community, labor and human rights, financial responsibility and the diversity; for finding the relationship between variables. He has chosen the case study for studying the data of the multinational buying office in the PRD and HR regions. The finding obtained from these case studies have indicated that environment, health, human rights, ethics and safety are more important factors than the financial responsibility, community and the diversity in the PSR practices. It is also indicated that the PSR practices are very important for the increased brand image, productivity, quality, customer loyalty and sales, risk management and ability to attract more customers and retaining the employees. The researchers have recommended that more research should be done over the PSR situation.

Oh \& Kim (2011) have explored the effect of B to B e-marketplace type on buyer-supplier relational advantages of e-marketplace and firm performance. They have used the variables including: information sharing, collaboration, trust, integration, communication, operational performance and financial performance. For analyzing the data, they have used the Pearson co-relational analysis. The results indicated that the buyer supplier relationship advantage of e-market is highly correlated with the all the above mentioned variables. Only, financial performance of the company is focused on the many to much e-marketplace relationship. The researchers have said that the only limited companies have become the part of this survey. That is why; future studies must focus on more companies, for analyzing the result.

Pazirandeh (2011) has sourcing in global health supply chains for the developing countries. He has incorporated the list of variables including: quality, customer rejection rates, delivery, quality control rejection rate, compliance with due date, flexibility, fill rate, delivery lead time, change in delivery dates, meeting the demand fluctuation, special request, reliability, empathy, responsiveness, access, assurance, communication, courtesy, competence, credibility, understanding,, costs, logistic, product range, purchase price, new product availability, recycled materials and additional features. He has a thorough review of several supply chain and purchasing journals and has developed the strategic criteria. The findings that were obtained have showed some historic strategies for decision making. The finding also indicated the models that have to be adopted for making the effective SCM. Quality is considered to be the most important element for making the product competitive, globally. The research suggested that the logistic, sourcing and supply chain journals must also become the part for conducting the future studies. 
Sander et al. (2011) have analyzed the impact of buyer firm information connectivity enablers on supplier firm performance. The variables they have selected to study are information sharing between the buyer and supplier, planning and operational info sharing, performance feedback between the supplier and buyer, buyer investment in the inter organization IT, communication openness between buyer and supplier and supplier performance. They have used the T-test and structural equation modeling for analyzing the data. The results obtained from these tests indicated that the performance feedback, information sharing between the buyer and supplier and the buyer investment in the inter-organizational IT are major components that dictate the communication openness between the buyer and the supplier. This buyer and supplier openness in communication thus plays a vital role in dictating the performance improvement of the business. The researchers have recommended that future studies must be conducted on focusing the buyer's perspective too.

Choo et al., (2009) have investigated the buyer and supplier relationships in Dongdaemun fashion market. They have established the relationship quality model. They have chosen the variables like relationship quality, price, design, communication, power balance, satisfaction, honesty, geographic proximity, trust, and strong supplier power, .power balance from mutual dependency, strong buyer power and power irrelevance from mutual independency. They have used mixed approach for analyzing the data. They have used the t-test, chi-square, regression analysis and factor analysis for estimating the results. The results indicated that the product design, supplier honesty and the quality of the product are essential elements for dictating the buyer and supplier's relationships. Ages, communication, designing factors and the geographical proximity are the major factors for dictating the relationship between buyer and supplier. While, the power balance and quality are least important factors for dictating the relationship. This research is limited to the fashion industry only; that is the reason; the future research must focus on the other geographical areas also.

Tantoush et al. (2009) have studied the impact of sanctions on buyer-supplier relationship in the Libyan oil industry. They have studied the variables like trust, communication, co-operation, relationship and commitment. They have collected the data by semi-structured interview and case study. The results obtained indicated that the trust, commitment, co-operation and the communication are not enough in highlighting the impact of the sanctions over the buyer and supplier relationship.

Kim (2008) has studied the effect of IT on Arms-Length buyer and supplier relationship. The variables that are chosen for the were investment, investment on assets specificity, capability for ITD, Supplier's non-contractible investment, supplier's revenue, transaction cost, need for the buyers, buyer's non-contractible investment, information sharing with the suppliers on demand, forecast, information sharing between MF and SP, the distortion of demand, RM inventory level, stock, RM backorder, production quality, need for safety, product variety level and the demand uncertainty. For studying the data; qualitative paradigm was selected. Theoretical analysis has given following conclusions. The efficient supply chain management is only possible by establishing the healthy relationship between the buyer and supplier. IT adoption and investment is also necessary for dictating the relationship between the buyers and the suppliers. Additionally, B to B e-commerce is necessary for the efficient management of supply chain.

Claro et al. (2006) have studied the coordinating collaborative joint efforts with suppliers. They have studied the effects of trust, network, firm size, transaction specific investment and information network in the Dutch flower industry. They have used the regression analysis for estimating the relationship between the variables. The result obtained have indicated that if buyer and supplier want to have trust, then they should have joint response for the better integration and safeguard of the investment.

Helm et al. (2006) have studied the suppliers' willingness to end unprofitable customer relationships. This research is based on the view point of suppliers to end up the relationship with the unprofitable buyers. The variables under consideration are the contribution margin, sales, cost, portfolio of customers, customer focused activity based costing, and customer's lifetime value and the customer focused scoring models. The researchers have used the exploratory method to estimate the results. They have found that companies in the German mechanical industry lack the knowledge about the customer valuation technique. The three different clusters of company have shown different point of views in maintaining the unprofitable relationship or breaking it. The researchers have suggested widening the scope of the research and including other industries, as well. Researchers have also suggested adding the role of valuation methods and implementation barriers.

Humphreys et al., (2006) have investigated the B2B commerce and its implications for the buyer and the supplier interface. The variables highlighted evolution of B2B commerce, establishment of buyer and supplier relationship, buyer oriented market, supplier oriented market, business-to-business intermediary, shifting focus of intermediaries, streamlining the order management process and enhancing the buyer and supplier coordination mechanism. They have used the qualitative paradigm and have highlighted factors that are affecting the B2B commerce. The findings obtained 
from the data have indicated that the electronic commerce is redesigning of internal organization process and buyer and supplier relationships. Innovation plays a vital role in managing the inter organization network and managing the supply chain of the organization.

Kannan \& Tan (2006) have studied the impact of supplier selection and buyer-supplier engagement on relationship and firm performance. The variables they studied are supplier selection, success of buyer supplier relationship, buyer supplier engagement and the firm performance. For evaluating the variables they have adopted structural equation modeling. The results indicated from this research demonstrates the buyer supplier engagement and supplier relationship performance have positive relationship with the business. They also showed that the successful relationship between buyers and supplier will work in favor of buyer and they will be gaining edge over competition. It will also give price competitive edge to the buyer.

Parker et al., (2006) have investigated the motivations for developing direct trade relationships. They have studied the variables like Quality and price, communication, information and innovation via qualitative approach. They have found that motivation plays an important role in dictating the buyers and supplier's direct and indirect relationship. This motivation ultimately leads to build the healthy relationships between the trade partners. This relationship will then minimize the inherent risk that is associated with the operating in an unpredictable environment. The researchers have suggested including the different commodities in the studies. The further recommended including the interviews of dyads for exploring their point of views.

Stemquist \& Chen (2006) has studied the food retail buyer behavior in the People's Republic of China: a grounded theory model. They have used the qualitative paradigm and highlighted the variables like objective information presented to a buyer about new product, evaluation of buyer, buyer's judgment over the profit potential, recommendation accepted or rejected by the buyers, buyer's inferences over the certain attributes, decision of the committee, withdraw from shelves, follow up evaluation and continuation decision, continue to sell, economic conditions, price, allowances and rebates, credit terms, support for cooperative advertising, sales force organization, services and functions, reputation and reliability, shipment conditions, logistic impact Volume/weight of the product, shelf space allocation, marketing support Introductory marketing campaign, impact on other products shelf allocation, continual marketing, retail price and implied gross margin, sales potential Rate of turnover, newness, product physical characteristics, packaging and the product psychological characteristics. They have used the case studies method for studying the data. The results indicated that all the factors, mentioned above are essential for food marketing. The results also showed that due to the cultural difference; it is very necessary for the buyers and suppliers to have close healthy relationship. This will solve the cultural complexities. The researchers have recommended replicating the same research in other parts of the world, as they have different cultural complexities.

Tyler et al., (2006) have investigated the relationship development in a multinational utilities network. They have estimated the variables by thorough case studies. The results attained from the case studies have indicated that strategic relationship management, service, relationship specific investment and adaptation, quality and exploratory exchanges is highly necessary for the credibility of buyer's network. The results further indicated that the quality, cost, relationship management and technology are the four basic criteria for purchasing. Users evaluate the products these before buying. The buyers also estimate the credentials of service providers. After this they confirm the information sharing and develop the long term relationship with the suppliers.

Ulaga \& Eggert (2006) have found out the relationship value and relationship quality- Broadening the nomological network of business-to-business relationships. They have studied the variables including the value, satisfaction, commitment, trust, expansion and leave. They have used the regression analysis and path coefficient analysis for estimating the results. The findings obtained from the analysis have showed that the value plays important role in reflecting the commitment, trust and satisfaction. Value also has a direct impact over the buyer's intention to expand the business with the particular supplier.

Cox (2004) has studied the business relationship alignment on the commensurability of value capture and mutuality in buyer and supplier exchange. They have studied the variables included reduced revenue, reduced returns, static revenues, increased returns, value for money, value for supplier, increased share of customers, constant increased in functionality, constant decrease in cost, and total increase in price and product/service profitability. They have used the case studies for analyzing the data. The results indicated that most of the suppliers and buyers admit that win-win situation is very necessary for the business; though they are not ready to develop such mutual relationship. The results also indicated that it is better to accept the win-lose relationship, sometimes.

Kim \& Michell (1999) have estimated the relationship marketing in Japan: the buyer-supplier relationships of four automakers. They have studied the four automotive dealers and their relationships. They have used qualitative 
paradigm and explored the variables like: sales, revenue, profitability, and numbers of employees. From case study analysis, they have found that the healthy relationship between the suppliers will ensure the attainment of more profits, increase sales revenue and less number of employee's requirements. The researchers also recommended that this research must be replicated, as it has wide scope.

Donald (1996) has explored the buyer and supplier Relationships. He has tried to get the answer that how to Build Successful Partnerships. He has studied the variables like: program, the client, the deadline, special request, communication, feedback and the competitive situation. He has used the qualitative paradigm of studies. He has found from the data gathered that by having the mutual relationship between the buyer and supplier, both will be able to get more value added services. He will also be able to eliminate the conflicts through communication. He also found that the relationship also helps in getting to know about the areas where one is not expert. This healthy relationship will eventually helps the suppliers to estimate the demand before the buyers get back to them.

\section{Research Methodology}

\subsection{Research Approach}

The deductive approach has been used for analyzing the relationship between the supplier and buyer's relationship and the Independent variables including communication, conflict solutions, profitability, value, satisfaction, commitment, trust, expansion and innovations. The research is based on the qualitative paradigm of studies.

\subsection{Data and Sampling Method}

The data about the buyer and supplier relationship has been collected from the different buyers and suppliers. The FMCG sector of Pakistan is being selected for analyzing the trends. The samples from this sector, has been selected randomly. The random selection of buyers and suppliers ensured that each and every one of the participant has equal chances of being selected. This also ensured that the research is not dictated by biasness and it is putting light over the facts.

\subsection{Research Instrument}

The data is being collected from the different buyers and suppliers that are dealing in the FMCG industry of Pakistan. Interview technique is being selected for collection of the valuable information from participants. Questionnaire has been prepared for ensuring the collection of the data. The questionnaire is putting light over the relationship of buyer and supplier and the other independent variables. The questionnaire is designed in English language so that it can be easily understood by the participants. The participations will be asked each question and they will be given appropriate opportunity to answer to these questions.

\subsection{Research Technique}

The data collected from the interviews will be explored. The researcher has analyzed each and every aspect of information provided by the suppliers and the buyers. The researcher has dug out the following aspects from the data collected. The analysis has shown the relationship between the relationship among the buyer and supplier and the independent variables like communication, conflict solutions, profitability, value, satisfaction, commitment, trust, expansion and innovations. The flow of the relationship along with the individual weight is being highlighted by the interview.

\section{Analysis and Findings}

Previous chapter stated the methodology of the study. This chapter presents analysis of findings.

\section{BUYER'S PERSPECTIVE}

\section{What is the importance of supplier in Pakistani Retail Market?}

\section{BUYER-1:}

Supplier is your $50 \%$ business partner. A good supplier gives $100 \%$ benefits to your business rather you can't even survive in Retail business without a good supplier. If he won't delivers your order on the right time then your competitor will take the benefits and will take an edge on you because he will get it before you do similarly if your supplier will not offer good rates then further in return you can't offer reasonable prices to your customer . Today's retail market has perfect competition you can see Hyper market, metro \& makro (although they are whole seller but still they are also catering the retail customer aswell), Agha's, Motas, paradise, Chase-up etc. There is a war going-on in this business, to beat each other; retail stores offers reasonable offers on products to attract customers and that only happens when they have the complete corporation of suppliers. If your supplier gives an advantage then only you can deliver it to you customer you can't do it on your own. In today's market customer is well aware of everything if you 
don't have the required product on your shelf with good prices then he knows where to find it and he will move to other retail stores, in this case you will lose your customer. Today customer want special offers and discounts and you can't give it to your customer unless and until your supplier becomes an equal stake holder in it.

If you don't have good suppliers then it's a death to your business and believes me you will not survive in this business with giants.

\section{What do you expects from a supplier?}

We expects full corporation from our supplier;

1. We want from our suppliers that they keep us inform about the new products

2. Good rates

3. Timely delivery

4. Give us good offers, like if we buy $10 \mathrm{pcs}$ of a certain item, on that they will give us $2 \mathrm{pc}$ free

5. Good discounts on rates

6. Understand our company policies and follow them.

7. Fair business with us.

8. Corporate with us in items that are slow moving or near to expiry. Return or exchange such items that are slow moving on our shelves or are near to expiry with other items we require

9. Try to collect payment on the decided date as it was decided at the time of dealing.

10. Bare the freight charges.

11. Give us the delivery as per the Purchase Order. Don't add anything other than the items written on P.O and specially don't add the quantity of the items other than the quantity marked on the P.O.

\section{What is the core issue you encounter with the supplier?}

Supplier delays the delivery although the date of delivery is been decided before the purchase in the deal but still they don't deliver it on time. That creates problems for us and distorts the whole lead time we estimated.

When we give order to a supplier for a certain item we keep stock in hand in warehouse by considering the lead time of the delivery process. Supplier gives us a date that he will deliver our order on this particular date but we keep 2 days more stock in our warehouse as a contingency what if the supplier gets late in delivering the order. But still sometimes we bare loss as the supplier gets late in delivering the order, it even cross the dates we have set as contingency. At this moment what really creates problem is mis-commitment; supplier starts mis-committing the dates and promises to deliver the order tomorrow and then day after tomorrow.

\section{What are the $\mathbf{5}$ basic issues you encounter while doing business with your supplier?}

First. Delay in the delivery is the basic issue we encounter while doing business with our supplier. If they don't deliver order on time then it becomes problem for us because what-ever quantity we keep-in as stock if the fresh delivery won't come on time then we will gets out of stock because in retail business you can't measure the behavior of purchase. One day you will have minimum sales volume but the very next day you will break the record of sales. So if your delivery will not reach on time you will be out of stock and your shelf will be empty of the product(s).

Second. Sometimes suppliers don't go as per the Purchase Order (P.O). They include certain items in the order which are against the P.O and are undesirable or in other case supplier sometimes adds in the quantity of a product against desirable quantity as per P.O. We discourage to take the items against the P.O then at this moment supplier try its level best to past those items and sometimes it leads to hard talk.

Third. Supplier increases the rates of the items uninformed and delivers the items with new rates. As per contract supplier is liable to tell us increased rates before the deliver and specifically the time of ordering. It becomes a problem when order is delivered with high rates uninformed because as per procedure if an item is re-purchased with new rates then first it has to be approved from the head of the department and after that data entry department will enter in into the data base.

Fourth. When there is a case of item return and exchange then supplier becomes reluctant in picking the returnable items and creates delays in the process that creates problem in bill payment. It's a liability on our side we have to pay the amount unless and until supplier don't return it back. In certain case supplier verbally agrees to return the item but don't pick it up as per the commitment now we have to spent lots of energy and time to ask the supplier to pick the 
items. Sometimes supplier don't pick it and after some time items are sent to warehouse and it remains their and forgotten but the problem is its still appears in our inventory and creates confusion in our inventory management.

Fifth. Especially in medicine supplier mix Near to expiry item with the regular expiry date items. Sometimes due to load of work our receiving section ignores it and that near to expiry item went upstairs on our store shelves and creates problem for us. They got expired on shelves in minimum time period and in other cases customer refuses to purchase those items.

\section{What can you do to maintain your relationship with your supplier?}

In order to maintain relationship with our supplier we have to work on the following quarters:

1. Give respect and time to the vendor.

2. Don't waste his time when he comes to collect the payment

3. Give him a fix date for payment collection

4. Everything should be decided in the beginning. All matters should be settling and decided before purchase.

5. We should corporate as an organization with the supplier at the time of receiving of order.

6. What if you were a supplier? How would you have reacted and acted in the current situation?

Defiantly if were to be mishandled and my payment will be delayed then defiantly my terms with the said buyer will become worse. I will try to avoid making business with such party or I will try not to do business in volume. I will try to work organized and be fair to my buyer so that my goodwill don't get shaded. if we see the other side of the picture we our self act as a supplier when we sail the product to local customers so we always take care of things such as we never cheat our customer we exchange things if they are exchangeable, we deliver the benefit to our customer when we get from our supplier. We try our level best to satisfy our customer and corporate with him/her at our level best.

If I were a supplier then I will try to fulfill all the requirements and rules and regulations that are set with me.

\section{Suggestions}

I strongly suggest that everything should be decided before making any business and both parties should stick to it. Secondly payment schedule should be followed and if there is any delay in payment then it's our duty to inform the vendor accordingly. Operations should be made strong internally so that supplier should not be mishandled or the delivery must not be mishandled.

Meetings with suppliers should be set in an organized manner so that purchaser should interact with supplier and give ample time to supplier and understand things and deliver the instructions to the supplier accordingly.

Working should be made to enhance the good-will of the retail store in a positive manner in the market so that suppliers corporate with you at the time when you delays their payment.

\section{This Analysis is on the basis of respondents answers}

Q1 Supplier is their (buyer's) business partner they can't survive without good supplier. In this competitive market where wholesale markets like makro etc. serve wholesalers, they take care of retailers as well. It is death of their business without good supplier. They can't survive in the presence of giant retailers.

Q2 They expect from supplier to inform about the new products, Good rates, On Time delivery, give them good offers and discounts on rates, Return or exchange, Bear the freight charges, Give them the delivery as per the Purchase Order Q3 miss commitment is an issue on delivery time. Late delivery creates problems for them.

Q4 Delay in the delivery is the basic issue. Sometimes suppliers don't go as per the Purchase Order, increase the rates of the items without informing them, item return and exchange specially in medicine supplier mix Near to expiry item with the regular expiry date items.

Q5 they can give respect and time to the vendor and can save his time by deciding all the issues in the beginning.

Q6 he would like to do fair business to maintain goodwill and to fulfill all requirements on time and on time and to work on pre settled terms and conditions.

Q7 business conditions should be settled before making any business and meetings with supplier should be set in organized way and working should be done to enhance the goodwill of store. 


\section{What is the importance of supplier in Pakistani Retail Market?}

\section{BUYER-2:}

Without a supplier we can't run any super market because he is the one who is supposed to provide goods as per our requirements timely. From supplier we can buy goods on credit or cash basis. He is our business partner who invest in our market on certain margin and provide us with the required product at our door step in whatever size shape and quantity we require ( generally in bulk quantity). He gives us benefit in payment terms by taking payment on credit. He can buy things from the sources and provides us, due to the wide range of goods in a retail market we can't run after every single product in market so a supplier's services are acquired who have a range of products that can be acquired from them. Sometimes they offer us extra discounts on bulk quantity which help us to control prices and offer competitive prices to our customers. Pakistani retail market is getting more competitive and tough competition is been seen in these few years. By the entrance of giants like hyper market and others competition has become tough so without a good supplier one can't survive in the current market structure.

\section{What do you expects from a supplier?}

We expects full corporation from our supplier;

12. He do business with us on credit

13. Give us good competitive rates

14. Timely delivery. His delivery lead time don't exceeds from more than 2 days.

15. Give us the required quantity and if he is unable to provide us the right quantity then he must inform us that he can't provide us with the required quantity so that we may try some other supplier.

16. If goods got stocked and are not selling then he cooperates with us and exchanges the items with other goods.

17. Give us original genuine goods. Give us right product on right rates on right time.

18. Give us good discounts and offers

\section{What is the core issue you encounter with the supplier?}

Order is not delivered on time and secondly at this point supplier lies to us and makes miss commitments. If we don't get goods on time then we won't be able to sell things and won't be able to generate revenue

\section{What are the 5 basic issues you encounter while doing business with your supplier?}

1. Delivery late, miss-commitments on delivery they commit to deliver us goods on the said date but delays it to many days

2. Delivery quantity doesn't meet the P.O quantity. If we ask for 12pcs of a certain good they give us 6 pieces and don't inform us that they don't have the required quantity. If they inform us on time then we can arrange the required quantity from other supplier. Sometimes they gives more quantity then required again it creates problem as the total amount of the delivery exceeds the P.O total amount.

3. They don't give us the appropriate rate. They quote us higher rates than other retailers, higher rates results in higher prices. Higher prices discourages customers

4. Try to paste us with $2^{\text {nd }}$ grade goods or copy of goods. Copied goods are cheaper and sub standard. They give us rates of original goods and try to give us copied goods

5. They don't cooperate with in after sales services of goods.

\section{What can you do to maintain your relationship with your supplier?}

Fulfill the commitments. If it is decided that we will give the payment in 15 days then it should be 15 days. Behavior with suppliers should be good and decent, we should respect him. Through good behavior we can get the flexibility in the payment as well. Sometimes purchaser tries to fool the supplier by telling the wrong rates to get better rates, this annoys them they already know all the bits and pieces; they know what other supplier is offering the rates. This results in mistrust between both the parties.

\section{What if you were a supplier? How would you have reacted and acted in the current situation?}

I will work strictly on principles; whatever I will commit I will fulfill it. If something happens in between I will communicate it to the customer accordingly so that my good-will will not gets hurt. I will try to get more orders and will try to deliver ever product whatever my customer is asking from me. 


\section{Suggestions?}

First of all we should build confidence within our self that we can do it. We should not follow our competitors footsteps we should have our own phenomena of doing business and we should have our own planning of executing our operations. On personal relationship with a supplier order should not be made and importantly orders should not be made on vendors/suppliers pressure. Supplier tries to pressurize purchaser to gain his own profits but purchaser should work on company's interests and make orders as per need.

\section{According to Buyer 2}

\section{This Analysis is on the basis of respondents answers}

Q1. Supplier is their (Buyer's) business partner and they can't run their business without good supplier because he is supposed to provide everything on time.

Q2. From supplier they require credit, competitive rates, on time delivery, required quantity, and exchange of goods, genuine gods and discounts offering.

Q3. On time delivery is core issue which leads to miss commitment from supplier side. Because of it they can't generate revenue.

Q4. According to him, late Delivery, miss-commitments on delivery, they don't meet required delivery quantity, they don't give us the appropriate and market competitive rates, they give us rates of original goods and try to give us copied goods and after sales services of goods are core issues of this business faced by suppliers.

Q5. They can fulfill their commitments make sure that if payment time is 15 days it should be 15 days not more. They can have good behavior.

Q6. He will work strictly on principles and fulfill his commitments and will try his best to deliver goods on time.

Q7. Building confidence to do what we want to do, we should plan and execute our own business policies and should make order according to need not on personal relationship basis.

\section{Supplier's Perspective}

\section{What is the importance of a buyer in Pakistan retail market?}

\section{Supplier-1}

We sell our product to buyer (retail market). They are the purchaser of our products and our business depends on it. We generate revenue from them; basically our business is meaningless without them we can't go directly to the end user we can't sell them directly because nature of our business is different we sell items in bulk quantity and end user don't buy things that frequently in that quantity. Our business core logic is doing business in bulk and in frequency if we don't move it like that then we can't generate profit basically we roll our money, we further invest it so if we don't do business in volume and frequency then we can't do business. That makes retailers our only and basic customers so importance a retail market buyer to us is very important.

\section{What do you expects from a buyer?}

Simply we only expects from our buyer to pay us our payment on the due dates. We roll our money they money we gets from the store we invest it further. Due to delay in payments we just got fed up, there should not be any miss commitment because it costs us. When the purchaser tell us the date and amount we further make commitments for our business operations but when they don't give us the payment on the informed date then our good-will distorts we are humiliated in the market our name gets dirty in the market, that we can't bare because we have to sit in the market, do business in the market for us good-will matters a lot. Secondly we expect from the retail store that our men should not be mishandled and their time should not be wasted because they have to go to our other customers for delivery or collection.

We expect an organized system from our customer and everything should be informed to us accordingly before making any kind of a business. All things should be decided and accordingly followed.

\section{What is the core issue you encounter with your buyer?}

The core issue we encounter with our buyer/customer is payment issue we want payments on time or it should be made in the date and time as committed. Usually we are doing business on credit so we decide terms of credit so payment should be done on the same terms. What buyer do it exceeds the payment from more than 30 days to 45 days and even more, they are taking rates like a customer who give us cash but due to volume we bare that but delaying in payment give us loss. Its injustice with us u know, we are cooperating with our customer but he is giving us loss from all angles 
that's unfair. Secondly time is money waste of time cost us more, when we send our guy to collect the payment their accounts department wastes time, our man has to go further to collect payment if he spends all of his time on one place then what will he do further.

\section{What are the basic 5 issues you encounter with your buyer?}

1. Payment not on time

2. Waste of time while collecting the payment

3. Misbehavior

4. Very strict in their own operations but weak in deliverance specially payment

5. Sometimes they mishandle the deliver they damage the pieces while receiving or in their own operation and blames us and try to return it back to us. Their lower staff damages the item and wrongly pottery that it was received damage.

\section{What can you do to maintain the relationship with buyer?}

Give genuine products to our customer, don't compromise in the quality or give what is asked for. Give delivery on time but sometimes things are not in our control as well which make the delivery late but will try our best to deliver the items on time. Give competitive rates

\section{Suggestions?}

Both sides should understand the problems of others, cooperates with each other. Things should be decided and mutually agreed before business. Fair business should be done from both sides and no lies should be said from both side.

\section{Supplier-1}

\section{This Analysis is on the basis of respondents answers}

According to Supplier 1,

Q1. They (Suppliers) can't reach to the end user and customer don't purchase frequently it is because they need buyer. Their business depends on frequency and only buyer can purchase frequently not end user.

Q2. They expect on time payments because we invest money again and again. Delay in payments makes our name dirty and wastes the time of our employers who expect collection on time.

Q3. Core issue is of payments. Some time buyer doesn't pay them on time and delays even many days after term of credits. That thing gives loss to the suppliers. When their collection staff goes to collect and could not get payment it wastes their time a lot.

Q4. Some basic issues faced by buyers are: No Payment on time, Waste of time while collecting the payment, Misbehavior and mishandling of goods.

Q6. They try their best to provide the genuine and same thing which was ordered on competitive rate.

Q7. Both sides should do the fair business and try to understand and cooperates each other.

\section{Supplier-2}

1. Indeed, Pakistan retail market is now going to become very attractive for everyone. Consumers have become smart buyers they want all goods under a single roof. Culture of retail market is flourishing in Pakistan now and high competition is been seen among retail super markets in these few days. Now, suppliers would have to play in a smart way to compete retail super stores (buyers) requirements. These buyers are our business partners we full fills their growing needs. We are the only source from where they can full fill their needs and they are the actual source for which we are doing business.

2. It's like I scratch your back and you scratch mine. We full fill their demands so we expect them to pay us good.

3. The main issue we have with our buyers is that they want the goods on urgent basis but still on cheaper rates. They expect everything from us but don't want to do anything from their side. At least give us the good rates if we are providing them bulk quantity in such limited time.

4. following are the basic 5 issues we encounter generally with all of our buyers; 
- They want delivery in very short time; they don't give us ample lead time and pressurize us to deliver the goods urgently.

- Payment delays occur, credit terms are set to 30days but still we get our payment in 45 days... even they take rates of cash payment schedule (in cash payment terms rates are a bit cheaper then credit term payment schedule because we keep our margin of 30days payment, as our money is stucked for 30days)

- They want A-class quality; they don't a single slightly damaged piece even a slightest defect causes us return of whole lot.

- They want exact quantity as printed on their P.O or else either they cut a percentage of our actual payment or black list us.

- They want all the services from us. They want us to deliver the items to their warehouses and even in the case of return they want us to pick them up from their warehouses.

5. As per today's economic recession which everyone is facing. To keep a running business and to keep a good buyer we have to provide best services as per their requirements to maintain current good relationship and future prospects.

6. If I place myself in buyer's place then I would have acted in the same way the buyer is acting and the points I have told you as core issue with the buyers would have been points in my policy.

7. I would suggest that both parties in this business should consider each other problems and help each other instead of putting the entire burden on other. Both parties are here to get profit it give and take basically, if you expect everything from supplier then buyer should also take care of supplier's basic need.

\section{Supplier-2}

This Analysis is on the basis of respondents answers

Q1. In flourishing culture of retail market, consumer needs everything under 1 roof. They are their (suppliers) business partner and we try to fulfill their needs.

Q2 .After fulfilling buyers demand they expect to be paid well.

Q3 .They provide goods on urgent basis to buyer and even on cheaper rates but they don't cooperates with us.

Q4 .Pressure for urgent delivery, Payment delays, quality and damages issues, required quantity. And delivery and sales return issues are core issues.

Q5. They should provide best services in this recession period.

Q6 .If he were buyer he acted in the same way as buyer acts now.

Q7. Both parties should understand the problems of each other and cooperates with each other because both are here to earn profit.

\section{Summary, Findings and Recommendations}

In the preceding chapters, the problem of the study was introduced; the related literature was reviewed; the methodology of the study was described and the results were analyzed. In this chapter, summary and major findings of the study will be catalogued and recommendations will be made.

\subsection{Summary}

The objective of this thesis is to examine the core factors that dictate buyer (Super Market) and Supplier (Distributor) relationship in retail industry. In this research, aspects has been studied that could have affected or affects the relationship of buyer \& supplier in positive or negative manner. The research has covered the retail market and will be dictating the key aspects of maintaining the healthy buyer and supplier relationships. This will be helping the retail owners and retail brands to gain the competitive edge from others and always remain ahead. This research will help both the stakeholders of this industry to maintain healthy relationships between them and indicates them that what the issues that create problems between them are. The specific objectives of this study were outlined as

Follows: 
(1) To investigate the core reasons that is affecting buyer and supplier relationship

(2) To determine the reasons that creates problems for buyers and suppliers separately

(3) To investigates the reasons that can maintain the mutual beneficial relationship with each other.

The thesis employed an empirical approach designed in three stages; aggregate and firm level analysis using official data, firm level analysis using survey and finally case studies aimed at providing deeper insights into the underlying issues observed in the survey findings. Three literature strands were adopted: spillover, cluster and network dynamics.

\subsection{Recommendations}

After conducting interviews from both the stake holders and analyzing their answers I recommend following points as recommendations which are as under;

1. Both parties should sit together and resolve their issue bilaterally. They should understand that without each other they can't survive in this competitive market.

2. Buyer should work on its internal infrastructure and organize its operations. They should eliminate all the elements that are damaging their relationship with their vendors. They should improve their receiving process and the transportation of goods from warehouse to Super market because in this process supplier complains that goods are been damaged and then they blame us of delivering damaged goods.

3. Payment schedule should be organized. Through record should be maintained for each single vendor according to credit/payment terms decided. Payments to suppliers should not be delayed and should be made as per commitment.

4. Days should be set for payments; vendors should be called on different days on the basis of product departments. This will eliminate the factor of hustle and rush of vendor on the same day and time. That will also reduce tension and the chances of conflict amongst the both parties and will also eradicate complains of vendors such as; misbehavior and waste of time.

5. Commitments from both sides should be followed as a religion.

6. Both the stakeholders should bridge themselves through better communication means and technology.

7. Suppliers should be fair in doing business with the buyers. There should be clear and honest business dealing because trust is the basic building block of any sort of a good relation. Prices should be fair and buyer should get what he has asked for he should not cheat.

8. Supplier should fulfill its buyer's demand as per commitment and if not then buyer should be apologized and informed before any delay. Delivery should be on time as committed with the goods and quantity as demanded.

\section{References}

Administrator. (2011, 02 14). The economy of pakistan 2011. Retrieved 11 29, 2011, from eezzi: http://www.articles.eezzi.com/economics/76-the-economy-of-pakistan-2011.html.

Choo, H. u., Jung, J.-W., \& Chung, I. H. (2009). Buyer-supplier relationships in Dongdaemun fashion market: relationship quality model. Journal of Fashion Marketing and Management, 13(4), 481-500. https://doi.org/10.1108/13612020910991358

Claro, D. P., Oliveira, P. B., \& Hagelaar, G. (2006). Coordinating collaborative joint efforts with suppliers: the effects of trust, transaction specific investment and information network in the Dutch flower industry. Supply Chain Management: An International Journal, 11/3, 216-224. https://doi.org/10.1108/13598540610662112

Cox, A. (2004). Business relationship alignment: on the commensurability of value capture and mutuality in buyer and supplier exchange. Supply Chain Management: An International Journal, 9(5), 410-420. https://doi.org/10.1108/13598540410560793

Donald, M. (1996). Buyer-Supplier Relationships How to Build Successful Partnerships. Society of Incentive \& Travel Executives (SITE).

Fro“dell, M. (2011). Criteria for achieving efficient contractor-supplier relations. Engineering, Construction and Architectural Management, 18(4), 381-393. https://doi.org/10.1108/09699981111145826

Hadisumarto, W. b., \& Abdul, G. (2010). Improving the effectiveness of Islamic micro-financing Learning from BMT experience. Humanomics, 26(1), 65-75. https://doi.org/10.1108/08288661011025002 
Hald, K. S., \& Ellegaard, C. (2011). Supplier evaluation processes: the shaping and reshaping of supplier performance. International Journal of Operations \& Production Management, 31(8), 888-910. https://doi.org/10.1108/01443571111153085

Helm, S., Rolfes, L., \& Günter, B. (2006). Suppliers' willingness to end unprofitable customer relationships. An exploratory investigation in the German mechanical engineering sector. European Journal of Marketing, 40(3/4), 366-383. https://doi.org/10.1108/03090560610648101

Humphreys, P., McIvor, R., \& Cadden, T. (2006). B2B commerce and its implications for the buyer-supplier interface. Supply Chain Management: An International Journal, 11/2, 131-139. https://doi.org/10.1108/13598540610652528

Kannan, V. R., \& Tan, K. C. (2006). The impact of supplier selection and buyer-supplier engagement on relationship and firm performance. International Journal of Physical Distribution \& Logistics Management, 36(10), 755-775. https://doi.org/10.1108/09600030610714580

Kim, J.-B., \& Michell, P. (1999). Relationship marketing in Japan: the buyer-supplier relationships of four automakers. Journal Of Business \& Industrial Marketing, 14(2), 118-129. https://doi.org/10.1108/08858629910258991

Kim, S. W. (n.d.). The Effect of Information Technology on Arms-Length Buyer-Supplier Relationship. The Asian Journal on Quality, 9(3), 57-69.

Lau, A. K. (2011). The implementation of social responsibility in purchasing in Hong Kong/Pearl River Delta. Strategic Outsourcing: An International Journal, 4 (1), 13-46. https://doi.org/10.1108/17538291111108417

Oh, S. J., \& Kim, S. W. (2011). The effect of B2B e-marketplace type on buyer-supplier relational advantages of e-marketplace and firm performance. The Asian Journal on Quality, 12(2), 189-203. https://doi.org/10.1108/15982681111158742

Parker, M., Bridson, K., \& Evans, J. (2006). Motivations for developing direct trade relationships. International Journal of Retail \& Distribution Management, 34(2), 121-134. https://doi.org/10.1108/09590550610649786

Pazirandeh, A. (2011). Sourcing in global health supply chains for developing countries. International Journal of Physical Distribution \& Logistics Management, 41(4), 364-384. https://doi.org/10.1108/09600031111131931

Sanders, N. R., Autry, C. W., \& Gligor, D. M. (2011). The impact of buyer firm information connectivity enablers on supplier firm performance. The International Journal of Logistics Management, 22(2), 179-201. https://doi.org/10.1108/09574091111156541

Simon, M. (2011, July 18). Junk food industry to determine kids. Retrieved 10 26, 2011, from Food Safety News: http://www.foodsafetynews.com/2011/07/junk-food-industry-determined-to-target-kids/

Sternquist, B., \& Chen, Z. (2006). Food retail buyer behaviour in the People's Republic of China: a grounded theory model. Qualitative Market Research: An International Journal, 9(3), 243-265. https://doi.org/10.1108/13522750610671671

Tantoush, J. O., Lettice, F., \& Chan, H. K. (2009). The impact of sanctions on buyer-supplier relationship within the Libyan oil industry. International Journal of Energy Sector Management, 3(2), 171-186. https://doi.org/10.1108/17506220910970579

Tyler, K., Stanley, E., \& Brady, A. (2006). Relationship development in a multinational utilities network. Journal of Services Marketing, 20/5, 333-345. https://doi.org/10.1108/08876040610679945

Ulaga, W., \& Eggert, A. (2006). Relationship value and relationship quality Broadening the nomological network of business-to-business relationships. European Journal of Marketing, 40(3/4), 311-327. https://doi.org/10.1108/03090560610648075 